\title{
Performance como tradução: política e arte indígena na cidade
}

\author{
Marcos Alexandre dos Santos Albuquerque ${ }^{1}$
}

Resumo: Este artigo analisa uma performance como parte essencial da experiência da etnicidade vivenciada por indígenas Pankararu na cidade de São Paulo. Fruto da política cultural de sua associação, essa performance se constituía em um ato de tradução intercultural que promovia uma experiência da etnicidade particular para esses indígenas.

Palavras-chave: indígenas, Pankararu, etnicidade, performance

\section{Performance as translation: politics and indigenous art in the city.}

Abstract: This article analyzes a performance as an essential part of the experience of ethnicity experienced by indigenous Pankararu in the city of São Paulo. As a result of the cultural policy of their association, this performance was an act of intercultural translation that promoted a particular experience of ethnicity for these indigenous people.

Keywords: indigenous, Pankararu, ethnicity, performance

1 Possui graduação em Ciências Sociais pela UFCG (2002), mestrado em sociologia pela UFPB (2005) e doutorado em antropologia social pela UFSC (2011). Atualmente é coordenador do N.A.d.A (Núcleo de Antropologia da Arte) na UERJ. Tem experiência na área de Antropologia, com ênfase em Etnicidade, Performance, Antropologia da Arte e Antropologia Visual, atuando principalmente nos seguintes temas: indígenas em contexto urbano, arte étnica, museus e vídeo etnográfico. Universidadde do Estado do Rio de Janeiro (PPCIS / PPGHA / UERJ). E-mail: uerjmarcos@gmail. com. ORCID: https://orcid.org/0000-0003-2396-6062. Lattes iD: http://lattes.cnpq.br/8192926134324071. Rio de Janeiro, Brasil. 


\section{Introdução}

Este artigo analisa uma performance feita de dança, cantos e indumentária que se constituiu como peça central da mobilização étnica de uma população indígena que vive na cidade de São Paulo, os Pankararu. Uma das principais questões da política cultural desse grupo é o trabalho de valorização de sua distintividade étnica a partir do incremento de sinais diacríticos. Essa política cultural tem a difícil tarefa de vencer uma série de preconceitos que pretendem descaracterizar os Pankararu como indígenas.

Os Pankararu que estão na cidade de São Paulo são oriundos da migração de membros do grupo de suas Terras Indígenas, localizadas no sertão de Pernambuco. Historicamente os Pankararu são fruto do aldeamento no século XVIII de uma gama de povos autóctones no sertão de Pernambuco. Esse aldeamento foi formado pela união, num mesmo local, de diversos povos com línguas e costumes diferentes. De maneira a normatizar esse aldeamento, os padres e administradores do estado instituíram nos seus relatórios a denominação geral para esses povos como sendo a de Pankararu.

Durante o século XIX, o aldeamento dos Pankararu se constituiu em um espaço para a proteção e adoção de escravos fugidos. No século XX esse território também incorporou a população branca sertaneja através de casamentos interétnicos. Desse modo, obviamente, uma série de mudanças fenotípicas, linguísticas e culturais aconteceu no seio dessa população híbrida, e se constituiu em um entrave ao reconhecimento deles como uma população etnicamente diferenciada.

Desse modo, foi apenas no ano de 1940 que essa população obteve, do Serviço de Proteção ao Índio (SPI), o reconhecimento de sua distintividade étnica e a delimitação de parte do seu território tradicional, que só foi regularizado em 1996, e outra parte em 2004. Sofrendo anos com a violência da luta pela terra, da violência institucional que retardou por décadas a demarcação e homologação de seu território, e da escassez de terras cultiváveis e de emprego nas cidades vizinhas, a partir dos anos 1950, assim como muitos nordestinos, os Pankararu também foram atraídos para a cidade de São Paulo a fim de tentar uma vida melhor, garantia de emprego e oportunidade de dar aos filhos educação e maiores chances de profissionalização.

Um importante elemento de reconhecimento dos Pankararu como indígenas, pelo SPI em 1940, foi o fato de que esse grupo realizava um ritual cuja última etapa consistia em uma dança cerimonial com o uso de uma 
indumentária, chamada de praiá. Essa dança (a dança do praiá) é o ápice de uma festa em homenagem as entidades espirituais (Encantados), em agradecimento pela intervenção na cura de uma determinada pessoa. Naquela época, o SPI identificou nesse elemento de cultura material (o praiá) uma marca de autenticidade e tradicionalidade que reforçava a legitimidade do pleito e a origem autóctone dos Pankararu.

Figura 1

Praiá. 11/ mar/1938. Brejo dos Padres, Tacaratu (PE). Autor: Luis Saia. (http://www.centrocultural.sp.gov. br/missao_p.htm)

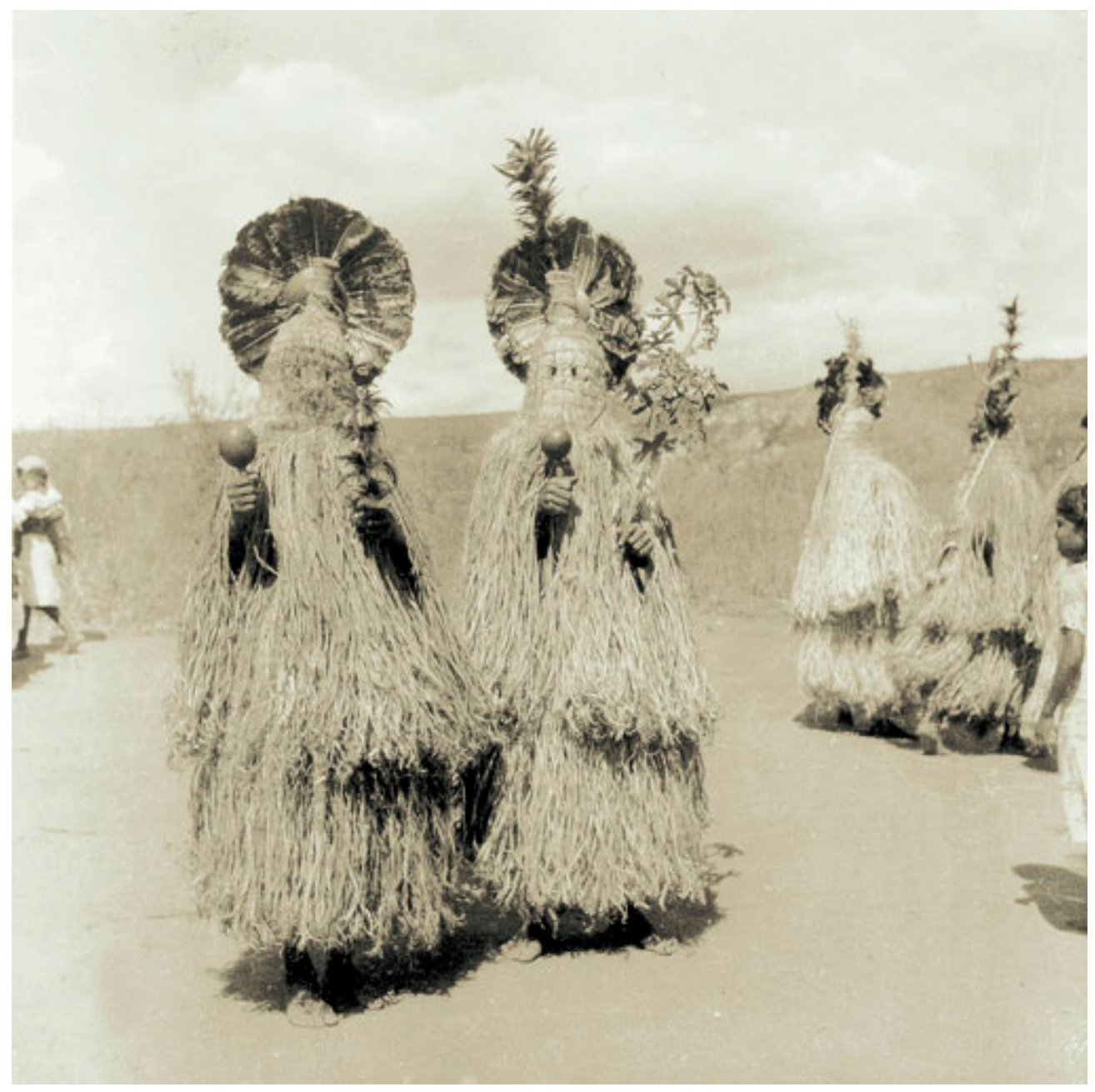

Em São Paulo, os Pankararu migrantes moravam em sua maior parte na favela do Real Parque (localizada no bairro do Morumbi), e formaram uma associação, a SOS Comunidade Indígena Pankararu (SOS-CIP), em 1994. A partir de então, começaram a se apresentar em diversos locais da cidade executando essa dança com o uso do praiá. Essas apresentações na cidade apareceram em um contexto muito preciso, quando após a constituição de 1988 emergiu com mais força na sociedade civil um tipo específico de demanda (digamos pós-moderna) por tradições, culturas, e autenticidades nativas que promoveram a visibilidade e o empoderamento das demandas 
indígenas. Nesses espaços de valorização do multiculturalismo (arenas), com todas as exigências por exotismo e autenticidade demandadas por seu público, os Pankararu construíram a performance "dança dos praiás" como um sinal diacrítico e como linguagem simbólica de ingresso em tais locais. Essas apresentações nas arenas da cidade pretendiam restituir aos Pankararu a imagem de "índios" e, portanto, reforçar a legitimidade de suas demandas políticas, culturais, educacionais, de saúde, entre outras.

A performance "dança dos praiás" emerge na cidade de São Paulo incrementando a participação dos Pankararu em espaços de visibilidade social e nos processos de diálogo e intervenção junto ao poder público e a sociedade civil. Essa performance se constituiu num projeto contra hegemônico no sentido de que ele se propõe a responder ao que denominei de preconceito de autenticidade (Albuquerque, 2017).

Esse tipo específico de preconceito não está claramente expresso e nem definido em termos e códigos jurídicos. Desse modo, não-nomeado, ele vem sendo recorrentemente negligenciado, fazendo-se passar por inexistente e inócuo. Atuando nas redes do poder simbólico (Bourdieu, 1989), o exercício desse tipo de preconceito é evidente na vida cotidiana dos indígenas. Portando, cabe ao pesquisador nomear e construir um caminho para que o tema possa vir à luz como uma categoria analítica.

Figura 2 Apresentação Pankararu. $s / d$. São Paulo (SP). Autor: Edson Nakashima.

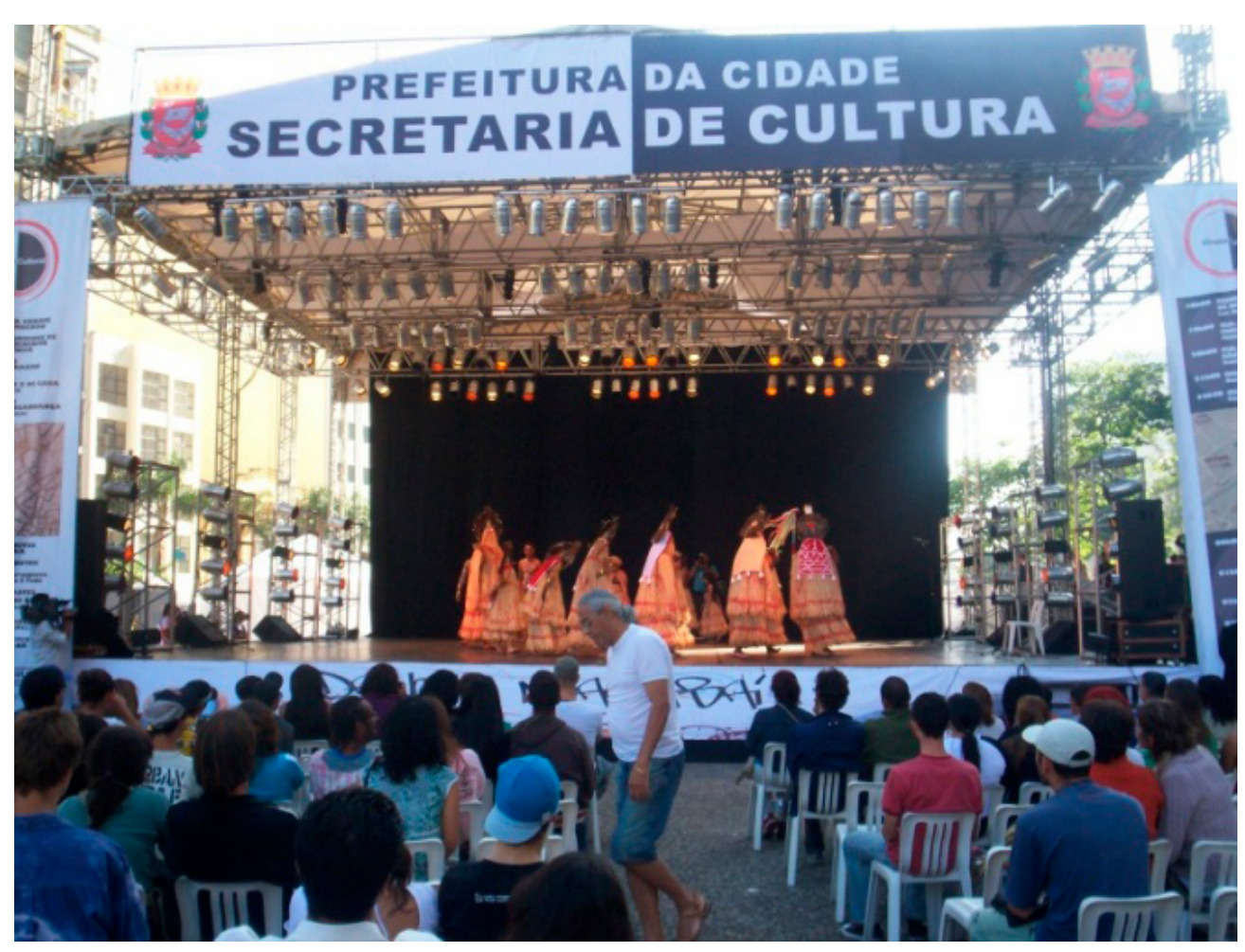


Neste artigo tematizo a performance a dança dos praiás como parte essencial da experiência da etnicidade vivenciada pelos Pankararu nas arenas de São Paulo. Fruto da política cultural de sua associação (SOS-CIP) essa performance se constituía em um ato de tradução intercultural que promovia um ato de consenso nas arenas de São Paulo e, assim, permitia uma experiência da etnicidade particular para os Pankararu dessa cidade.

Essa performance é pensada aqui como uma imagem, isso significa que a dança dos praiás era naquele contexto o signo de alteridade Pankararu mais valorizado tanto pela comunidade indígena quanto pelas arenas de São Paulo. Como bem colocou Novais (2001: 16) os "signos de alteridade são sempre imagens. Ou seja, são signos de alteridade que só conseguem realizar a comparação entre nós e os outros através da afirmação, jamais da negação. Ao contrário do texto, a imagem afirma positivamente, não tendo em seu léxico a negação". Pela utilização estratégica de um padrão imagético, a imagem do "índio", os Pankararu da SOS-CIP cooptavam essa imagética na atuação positiva do poder (Foucault, 2009).

A comunidade Pankararu em São Paulo aparece no contexto das arenas da cidade no momento em que a SOS-CIP é criada e institui uma política cultural cujo maior símbolo é a performance da dança dos praiás. Essa performance se constituiu em uma tradução intercultural cuja estética e poética (poesis) encontrou referência no quadro simbólico dessas arenas, lembrando aqui as definições de campo e habitus de Bourdieu (1989).

\section{Performance como tradução: a experiência da etnicidade}

A noção de situação social de Gluckman serviu de modelo para Oliveira (1988) na elaboração da noção de situação histórica. Segundo essa noção teórica, os indígenas brasileiros na atualidade, na sua grande maioria, devem ser pensados como fazendo parte de quadros sociais onde são evidentes "modelos ou esquemas de distribuição de poder entre diversos atores sociais" que mantém, assim, padrões de interdependência e de conflito.

Nesse sentido, a performance da dança dos praiás em São Paulo se constitui em uma imagética (performance imagética) porque ela é em si mesma uma imagem de conciliação, um espelhamento, um signo de alteridade (Novais, 2001) que só tem efeito numa determinada situação histórica vivida pelos Pankararu nas arenas de São Paulo. É nesse espaço que um tipo específico de senso comum da etnicidade promove uma experiência da etnicidade na qual a performance permite uma "experiência em relevo" (Bauman, 1977). 
Deste modo sigo Valle (1999: 279) que no seu estudo sobre a construção da etnicidade nas situações étnicas Tremembé (no estado do Ceará) preteriu o estudo das fronteiras e das identidades étnicas e em lugar procurou mostrar "o aproveitamento e a difusão do mesmo leque de categorias e de articulações simbólicas similares pelos atuais Tremembé e também por seus oponentes", ou seja, aqueles que negavam existir diferenças étnicas. Nesse sentido, o autor percebeu "várias singularidades ou vias de pensamento que tem proeminência étnica", e assim destacou a existência de "várias formas de discurso e seu peso político desigual no campo semântico da etnicidade". Por esse procedimento, o autor conseguiu demonstrar que naquela situação étnica existia uma experiência da etnicidade que era vivenciada pelos Tremembé de uma maneira singular, processual e não substantiva.

Também observei nas arenas de São Paulo, tal como Valle (1999: 331) no seu estudo sobre os Tremembé, que "a semântica da etnicidade possuía uma abrangência que se dispersava para além das situações, dos contextos interétnicos, constituindo uma 'tradição' genérica a respeito do 'índio'”. E, nesse contexto teórico, em ambos os casos "os elementos que caracterizavam as similaridades estruturais (...) foram encontrados nas interpretações do campo semântico da etnicidade por parte de todos aqueles grupos e atores sociais em divergência e conflito com os índios". Assim, o campo semântico da etnicidade funcionava como "matriz de interpretações que combinavam elementos e categorias com significados bem opostos", portanto, o campo semântico "tinha uma estruturação de caráter pluralizado, permitindo aproveitamentos 'discursivos' de significação antagônica" o que permitiu ao autor propor que ali não existia "redundância entre as interpretações étnicas" (Valle, 1999: 332).

Desde modo, "é a perspectiva da experiência da etnicidade que pode mostrar, de modo radicalmente positivo, que não existia redundância cultural entre os Tremembé e seus oponentes" (Valle, 1999: 333). E isso porque "a experiência deve ser vista como uma estrutura processual, disruptiva, sem ser rotineira, casual ou ordinária (Turner, 1986b:33-43)" (ibid.). Esse autor cita Bruner para quem as manifestações culturais são "unidades estruturadas da experiência" que projetam em seus participantes, tanto para aqueles que a produzem quanto para a audiência "um modelo específico de como experimentá-las". É assim que a experiência estruturada em uma forma virtual realiza a convergência "de situações passadas e presentes" ao mesmo tempo em que as projeta para o futuro (ibid.: 334 ).

Como toda experiência vivida socialmente, a da etnicidade também não é reiterativa, "pois toda vez que se repete ocorre um movimento de ino- 
vação", sendo assim, "a experiência pode ser vista como uma estrutura processual" (ibid.). Deste modo, os Pankararu em São Paulo também realizavam o que Valle encontrou entre os Tremembé, ou seja, como eles "se aproveitavam de modo singular e ativo da semântica da etnicidade, construindo interpretações positivas, perorando vorazmente por combinações semânticas, modelando sua experiência da etnicidade". (Valle, 1999: 335).

Sobre a noção de experiência da etnicidade no contexto da performance da dança dos praiás Pankararu, sigo o modelo proposto por Valle (2005: 214) e entendo experiência como uma "estrutura processual, sempre associada às expressões culturais, à reflexividade e à construção de interpretações". Esse processo deve ser entendido como um "processo estruturante de 'auto-modelagem'" (ibid.), assim, em arenas onde a identidade está em disputa e construção, os atributos étnicos devem ser pensados como "culturalmente construídos e, portanto, inventados, no sentido antropológico, na própria história do grupo" (Valle, 2003: 257).

Acredito que a performance da dança dos praiás, na cidade de São Paulo, produzia o tipo de efeito descrito por Valle (2005: 214-5) onde a performance funcionava propriamente como encenação ao produzir "certos efeitos dramáticos" e assim promovia "identificações, expondo uma imagem pública indígena", comunicando uma identidade étnica pelo uso de uma linguagem visual e, portanto, prescindindo da linguagem verbal.

Como imagem paradigmática e ideal, a "apresentação", sua estrutura, seu léxico (Novais, 2001) positivava as ambiguidades e as valorizava. Essa imagem, como símbolo e poder, era a lembrança e a atualização da violência simbólica colonialista, mas, ao mesmo tempo, era por isso mesmo, sua contestação. $O$ ato performático é o ato conciliatório, mas não de uma conciliação em termos de mútuo entendimento/acordo sobre um tema, antes, tratava-se de um ato de tempo que apenas momentaneamente promovia uma conciliação.

Essa conciliação era, portanto, estratégica, ela permitia a reunião das pessoas em torno do evento, ela pressupunha a conciliação que anunciava. Garcia Canclini (2006: 130) escreveu que "a identidade é uma construção que se narra", penso também que a identidade é uma performance que se realiza. Como escreveu Stuart Hall (2006: 71), "a moldagem e a remoldagem de relações espaço-tempo no interior de diferentes sistemas de representação têm efeitos profundos sobre a forma como as identidades são localizadas e representadas", era assim que a performance promovia uma experiência étnica para os Pankararu a partir da manipulação estratégica de noções e 
categorias que não estavam dados nos conteúdos semânticos ou simbólicos propriamente, mas na forma como os elementos estéticos/cinéticos - sensíveis da performance atuavam no contexto das arenas paulistas.

Assim, a experiência da etnicidade que a performance promovia era parte de uma política cultural da SOS-CIP. Essa performance criticava a atualização do poder tutelar através do preconceito de autenticidade, pois, ao cooptar as categorias desse tipo de preconceito ("assimilados", "aculturados" e "desaldeados") na "apresentação", as contestava. Nessa performance, menos do que reificar tais categorias como substância e conteúdo, sua poesis, seu efeito dramático, estético, sensível e imagético as cooptava de forma positiva e contra-hegemônica. Como drama estético-sensível, o ato performático contestava a violência simbólica colonial ao restituir aos Pankararu a "cara de índio", a "língua de índio" e o "lugar de índio" contestando assim, reciprocamente, as noções de assimilados, aculturados e desaldeados.

Desse modo proponho pensar a dança dos praiás realizada pela SOS-CIP pelo paradigma da performance tal como definido por Bauman (1977). Bauman (ibid.) definiu performance como sendo um tipo de evento comunicativo onde a função poética é privilegiada. Nesse sentido, a experiência suscitada pela performance está diretamente relacionada a esses aspectos estéticos e poéticos que na sua maioria são produzidos por vários meios promovendo uma sensação de sinestesia. Portanto, a performance tende a produzir a sensação de estranhamento do cotidiano, valorizando essa experiência como singular.

Como destacou Langdon (2009: 255), na performance sua função poética ressalta o modo de expressar a mensagem e não o seu conteúdo. Diferente de outros gêneros de atos de comunicação, a performance como paradigma defendido aqui "distingue-se primariamente por uma situação onde a função poética é dominante no evento de comunicação. A experiência é um elemento importante invocado pela performance e é uma consequência dos mecanismos poéticos e estéticos, sendo expressados simultaneamente através de vários meios comunicativos (Sullivan, 1986)" (Langdon, 2009: 09).

Para Langdon (2009: 258) os atos performáticos são estruturados de várias maneiras onde a "participação também é socialmente construída - os papéis que os participantes assumem (ator, plateia, etc.) e quem tem direito de ocupar um papel específico". Nesse sentido, a performance como paradigma é uma "categoria universal, no sentido de que corresponde a eventos que acontecem em todas as culturas e que todas as sociedades humanas têm vários gêneros de performance, especificamente marca- 
dos pela função poética, e que exibem as características descritas acima" (ibid.). Por ser geral e comum a todas as formas de sociabilidade descritas na literatura antropológica, a performance se coloca como o lugar ideal e pragmático das traduções interculturais.

Desse modo, acompanho Langdon (ibid.: 262-3) e proponho definir a performance da dança dos praiás através de suas cinco qualidades inter-relacionadas. Essa autora denominou que essas cinco qualidade "são compartilhadas pelas abordagens de performance, e que, de fato, formam um eixo dos diversos usos do termo de performance". São elas:

Experiência em relevo: Performance se trata de experiência realçada, pública, momentânea e espontânea. Em seu livro clássico, Bauman define a experiência em relevo como um evento artístico que envolve o ator (performer), a forma artística, a platéia e o contexto para criar uma experiência emergente (1977: 44). Turner (2005) e Schechner (1992) a definem como um comportamento intensificado, que é público e que inclui as artes performáticas, a política, a medicina e a religião. Para eles, a performance é um tipo de evento situado, em que o foco está na expressão estética e não no sentido literal.

Participação expectante: Esta qualidade trata da participação plena de todos presentes no evento para criar a experiência. Não trata puramente de ação normativa, nem de uma leitura semântica dos símbolos, mas de uma interação na qual o significado emerge do contexto (Schieffelin, 1985). O contexto se torna essencial para entender o sentido do evento e as interações entre os participantes produzem uma força retórica (Bloch, 1975; Csordas, 1983; Laderman e Roseman, 1996) que transforma a experiência dos participantes, ainda que apenas momentaneamente.

Experiência Multisensorial: Indo além dos limites da analise semântica do rito, a experiência de performance se localiza na sinestesia, ou seja, na experiência simultânea dos vários receptores sensoriais recebendo os ritmos, as luzes, os cheiros, a música, os sons em geral e o movimento corporal. A recepção simultânea de vários recursos cria uma experiência unificada (Basso, 1985; Schieffelin, 1985; Sullivan, 1986), uma experiência emotiva, expressiva e sensorial.

Engajamento corporal, sensorial e emocional: Como é característico na antropológica contemporânea, tanto quanto em outros campos intelectuais atuais, o paradigma do corpo e "embodiment" (corporificação) (Csordas, 1990) também faz parte das análises de performance, como demonstram particularmente bem as pesquisas sobre a eficácia terapêutica da performance, uma discussão que visa entender a possibilidade de transformação fenomenológica no nível mais profundo do corpo, rejeitando uma divisão cartesiana de experiência, que separa o racional do emocional e do corporal.

Significado emergente: A noção de cultura é pensada como um processo social contínuo, em que "novos significados e valores, novas práticas, novos significantes e novas experiências estão sendo continuamente criados" (Williams, 1973: 11, apud Bauman, 1977: 48). O modo de expressar se localiza no centro de performance, não só no significado semântico ou referencial, como é o caso das análises da antropologia simbólica clássica. Como consequência, o conceito de performance implica na experiência imediata, emergente e estética. 
Estas cinco qualidades formam no campo diverso e polissêmico da performance um "ponto de partida para pensar a performance como um paradigma conceitual" (ibid.).

Exposto esse princípio teórico passo a seguir a tematizar a condição da performance da dança dos praiás em contextos chave nos quais ela era a imagem hegemônica que moldava a política cultural da SOS-CIP.

\section{Ato de consenso: a "cultura" e a "política" da performance}

O projeto "Saberes do Brasil", através do espaço da ONG Casa Mestre Ananias e em parceria com os Pankararu da SOS-CIP, realizaram em 2008 uma oficina para crianças carentes, onde foi possível observar um flagrante da luta pela divisão entre consenso ("cultura") e dissenso ("política") que a performance representa. Segundo o site do projetol ele se constitui em "uma nova forma de desvendar os aspectos essenciais da cultura brasileira relacionados à gastronomia, cultura de raiz, costumes e música". O projeto lançou o livro "Brasil a Gosto", cujo conteúdo contém "a receita de como fazer o Brasil", onde se propõem entre outras coisas mostrar os "sabores típicos e exóticos processados de maneira artesanal e contados através da poesia" e a "miscelânea de qualidade totalmente nacional, tipo exportação e pronta para ser digerida".

A Casa Mestre Ananias (Centro Paulistano de Capoeira e Tradições Baianas)2 está localizada no bairro do Bixiga, centro de São Paulo. Em seu site está definida como sua missão, "configurar-se como polo sócio-educacional na cidade de São Paulo, pelo desenvolvimento de vivências com a cultura afro-brasileira. Fortalecer a comunidade do Bixiga, a partir do trabalho com crianças e jovens, visando à integração social, à cidadania e à elevação da autoestima".

No texto do projeto do workshop para a apresentação dos Pankararu na "Casa Mestre Ananias", a SOS-CIP propunha que a oficina fosse sobre "Canto e Dança Indígena Pankararu". O texto dizia na sua introdução que

1 http://www.saberesdobrasil.com.br/ (acessado em 02/09/2008).

2 https://mestreananias.blogspot.com (acessado em 23/12/2008). 
o projeto iria "apresentar um primeiro contato com a cultura tradicional do Povo Pankararu através do diálogo e interação com os participantes, apresentação de vídeos e músicas, bate-papo e oficina musical". O objetivo era o de "mostrar um pouco da cultura indígena brasileira, tão multifacetada, a partir da visão dos indígenas Pankararu sobre sua história e seus costumes". Como justificativa, o texto apontava principalmente o fato de que nos grandes centros urbanos existia "um grande distanciamento e desinteresse em relação às culturas indígenas" e que, portanto, "faz-se necessária a presença de atividades que estabeleçam um contato e apresentem as histórias e a situação atual das questões indígenas".

Desse modo, o texto propunha que a oficia fosse desenvolvida prioritariamente com uma apresentação da dança dos praiás. Essa "apresentação" era dividida entre uma atividade que a "oficinera" realizaria com as crianças para introduzi-las ao tema do "uso e manuseio dos instrumentos tradicionais da comunidade (gaita, maracá, rabo de tatu) usados durante os momentos cerimoniais, com a participação especial de crianças da comunidade [Pankararu]", e, a seguir, uma "apresentação" da dança dos praiás.

Após a palestra da "oficinera" Dora (liderança da SOS-CIP) foi aberto para o público fazer perguntas para ela. Os adultos foram os únicos que fizeram perguntas, basicamente as perguntas foram feitas pelos coordenadores da Casa Mestre Ananias.

A primeira questão levantada por um desses coordenadores foi a seguinte: "quando eu vi vocês assim..., eu queria que você falasse a respeito disso, que deve acontecer principalmente aqui em São Paulo. Eu, a princípio, falei, "puxa, não parece índio", isso foi rápido, foi a minha primeira sensação. Eu queria que você falasse um pouquinho sobre isso." Outra questão colocada foi sobre a lei 11.645/083: "vocês estão propondo material didático? Eu queria saber como essa discussão tá funcionando [na comunidade Pankararu]". A última questão colocada foi: "você, como indígena, o que você pensa do branco? O que o branco deixou de bom, de ruim? Qual sua visão da situação indígena em relação ao contexto do branco que domina?"

Dora estava respondendo cada uma dessa perguntas e contextualizando os Pankararu de São Paulo a partir dessas questões quando, em determi- 
nado momento, a coordenadora do projeto "Saberes do Brasil" a interrompeu com o seguinte argumento:

Dora, só um instante, por favor. Eu tô querendo mudar um pouquinho a dinâmica da oficina porque eu tô querendo que as crianças aproveitem um pouco mais dessa oficina. A gente tá fazendo perguntas muito maduras pra compreensão deles. Só pra vocês entenderem a oficina de hoje, o tema é o toré, que é a dança, uma tradição do povo Pankararu. Então eu tô querendo que a gente enfoque mais na dança. Aí vou deixar a Dora conduzir daqui pra frente, agradeço a compreensão.

Dora, educadamente reconheceu que a conversa estava sendo direcionada para questões mais "políticas" que "culturais": "é porque eles estão querendo conhecer o contexto histórico... mas o horário não tá propício...", a coordenadora do "Saberes do Brasil" emendou dizendo: "não é nem isso a questão. A gente até tem um horário pra trabalhar mais essas questões. Mas o projeto, 'Saberes do Brasil', que programou a oficina, programou a dança. A gente tá dentro de um calendário trabalhando Nordeste brasileiro e hoje o tema é a dança, o toré dos Pankararu". Desse modo a Dora procurou encerrar: "então tá. Os adultos vão ficar na vontade de mais perguntas, a gente faz em outro horário", e a coordenadora do "Saberes do Brasil" encerrou com a frase: "pode fazer as perguntas, mas dentro desse contexto". ${ }^{4}$

Após essa interrupção, a conversa praticamente terminou e prontamente foi proposto que a "apresentação" começasse, momento em que Bino (cacique e presidente da SOS-CIP) e os praiás entraram no centro da Casa e derem início à dança dos praiás que durou cerca de uma hora. Na sequência, o público e os Pankararu confraternizaram com um lanche e conversa descontraída. Nessas conversas uma das coordenadoras da Casa Mestre Ananias aproveitou o momento em que Dora e Bino estavam a sós com ela e pediu desculpas pela interrupção da coordenadora do projeto "Saberes do Brasil". Explicou que para os membros da Casa o tema da "política" era de suma importância e que o projeto "Saberes do Brasil" não era parte da Casa, mas que estavam trabalhando em parceria naquela ocasião. Lembrou ainda que gostaria que os Pankararu voltassem em outra ocasião para dar continuidade ao debate "político e cultural".

Na medida em que a atividade se destinava ao tema da "cultura", a "políti-

4 Esta flagrante está no vídeo São Paulo: A Terceira Margem Pankararu. [https://youtu.be/ RN1BUPJPqZM] 
ca" parece ter sido um tema "clandestino". Mas as conversas de bastidores revelaram que a "cultura" Pankararu estava ali para moldar o debate sobre os Pankararu de forma geral, abarcando "cultura", "política" e história social do grupo, e que nesse sentido as crianças não deveriam ser excluídas do debate sobre essas questões.

A matéria produzida pela Casa Mestre Ananias, e disponibilizada em seu site, reforçou através das imagens o lado "cultural" da atividade, enfatizando a dança dos praiás, embora o texto enfocasse substancialmente o tema da "política" e da história social dos Pankararu. A matéria foi publicada no dia 20/10/2008, com o título "O Toré dos Pankararu e o Contato com os Encantados".

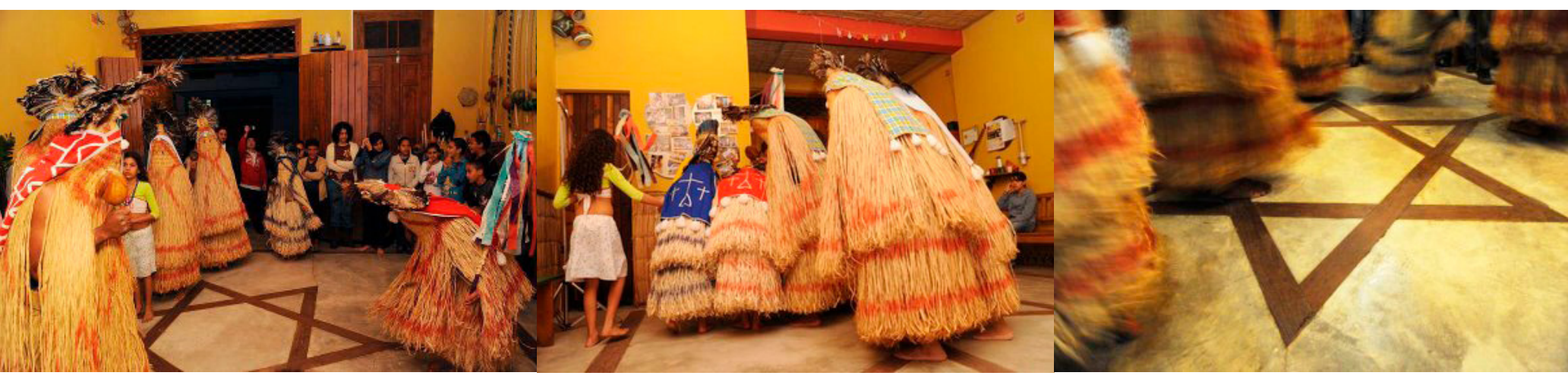

Figura 3

O Toré dos Pankararu e o Contato com os Encantados. 20/10/2008. São Paulo (SP)

Autora: Brígida Rodrigues "Di Lua" Fonte: mestreananias.blogspot. com/2008/10/o-tor-dos-pankararu-e-ocontato-com-os.html
Também em 2008 os Pankararu foram convidados para fazer uma "apresentação" na Sociedade Amigos do Real Parque (SARP), entidade que mantém uma sede nesse bairro e realiza gratuitamente atividades educativas e culturais direcionadas às crianças da favela do Real Parque. Foi distribuído um "convite individual", imprescindível para o ingresso na SARP naquele dia. O texto do convite diz, "SARP - SOCIEDADE AMIGOS DO REAL PARQUE e a tribo PANKARARU REAL PARQUE Convidam para a apresentação da Dança do Toré, cultura da tribo indígena Pankararu, natural de Pernambuco que tem parte de seus integrantes residindo no Real Parque - SP". 
Figura 4

Convite para a apresentação da Dança do Toré na

Sociedade Amigos do Real Parque

O texto do cerimonial revela um pouco o quadro social no qual estão os Pankararu no contexto do Real Parque:

\section{CERIMONIAL EVENTO PANKARARU}

$10 h 30$ - Recepção dos convidados:

Portão: Eduardo recebendo os convites e indicando entrada dos Pankararu pela escada lateral e autoridades pela escada central

Escada principal: Danielle receberá e acompanhará as autoridades e convidados da SARP até o Dr. Sodré que estará esperando na entrada no salão.

$10 h 50$ - Rosalie e Dr. Sodré convidam as autoridades e convidados da SARP a se dirigirem para a quadra, (sentarão do lado esquerdo da quadra).

11 h00 - Rosálie chama o presidente da SARP, Dr. Sodré para a abertura do evento dando as boas vindas e agradecendo a presença de todos.

11h05 - Rosalie convida a agente comunitária da Associação Pankararu, Sra. Dora para fazer uma síntese do significado da Dança do Toré, (dando início logo em seguida a apresentação)

11 h15 - Dança do Toré - Cerimonial religioso da tradição Pankararu

11 h45 - Encerramento da apresentação pela Sra. Dora

11 h55 - Rosalie chama o presidente da SARP, Dr. Sodré para fazer o encerramento.

12 h00 - Rosalie convida as autoridades e convidados da SARP e o representante dos Pankararu, Sr. Bino, a se dirigirem para o refeitório e os índios Pankararu tomarão o lanche que será oferecido na própria quadra próxima as pias e bebedouros.

Destaco nesse roteiro do evento algumas questões que revelam uma relação de classe com os Pankararu e demonstram a manutenção de uma dis- 
tância social baseada na origem social, no local de moradia e no poder econômico. Assim, o roteiro que foi entregue a Dora quando ela chegou tinha uma organização de horário extremamente rigorosa. Como era domingo, as "autoridades" e os "convidados" tinham outros programas a cumprir naquele dia e não podiam se demorar muito, sendo assim, o evento tinha de ser notadamente rápido, menos de duas horas, das 10h30min às $12 \mathrm{~h}$.

Desse total, para a "dança do toré" o tempo reservado foi de apenas 30 minutos. As "apresentações" dos Pankararu no Real Parque costumam demorar o dia inteiro, se constituindo em um verdadeiro "cerimonial Pankararu". A extrema rigorosidade do horário se deu como forma de se contrapor ao modelo dos indígenas que vão para tais eventos dispostos a passar o tempo que for necessário para isso, o que de forma geral acaba sempre incorrendo em atrasos e portanto na extensão do horário previsto. Assim, com tal rigor a organização do evento na SARP queria restringir também os longos discursos dos indígenas e também a longa "apresentação" da dança dos praiás.

Além disso, o processo de exigir um convite se devia ao fato de que era necessário restringir o número de participantes indígenas a fim de manter o espaço transitável e também como forma de controlar o lanche servido. Assinalo que em nenhuma ocasião das festas dos Pankararu no Real Parque há a restrição do número de convidados, pelo contrário, "quanto mais, melhor", pois o que tais eventos pretendem, dentre outras coisas, é tornar visível a presença do grupo na região e sua distintividade étnica. Portanto, sempre é franqueado o ingresso de qualquer pessoa nas festas promovidas pela SOS-CIP, e os Pankararu sempre procuram distribuir o almoço ou lanche tendo em vista o número de pessoas presente, para isso não economizam, como também é de costume na aldeia, para servir bem aos convidados.

Como diz explicitamente o roteiro do evento, "Portão: Eduardo recebendo os convites e indicando entrada dos Pankararu pela escada lateral e autoridades pela escada central. Escada principal: Danielle receberá e acompanhará as autoridades e convidados da SARP até o Dr. Sodré estará esperando na entrada no salão." Assim, estava um funcionário na entrada da SARP recebendo os convites e indicando a entrada, sendo que os indígenas deveriam entrar por um lado e sentarem-se em lugares predeterminados, as autoridades e outros convidados entrariam por um outro lado, seriam recebidos pelo presidente da SARP e sentariam num lugar separado dos indígenas, "10h50 - Rosalie e Dr. Sodré convidam as autoridades e convidados da SARP a se dirigirem para a quadra, (sentarão do lado esquerdo da quadra)." 
Combinei com Dora que filmaria a "apresentação" e ela e sua filha, Ingrid, fariam as fotos, que serviriam para mostrar como foi o evento como um todo. Nessas fotos ficam evidentes os espaços bem delimitados entre os indígenas e as "autoridades" e "convidados", pré-determinados e separados fisicamente (será que somente fisicamente?). As fotos mostram as "autoridades e convidados" sentados do lado esquerdo da quadra em cadeiras enfileiradas lado a lado:

Figura 5

Autoridades e convidados. 20/07/2008. São

Paulo (SP)

Autora: Ingrid

Pankararu.

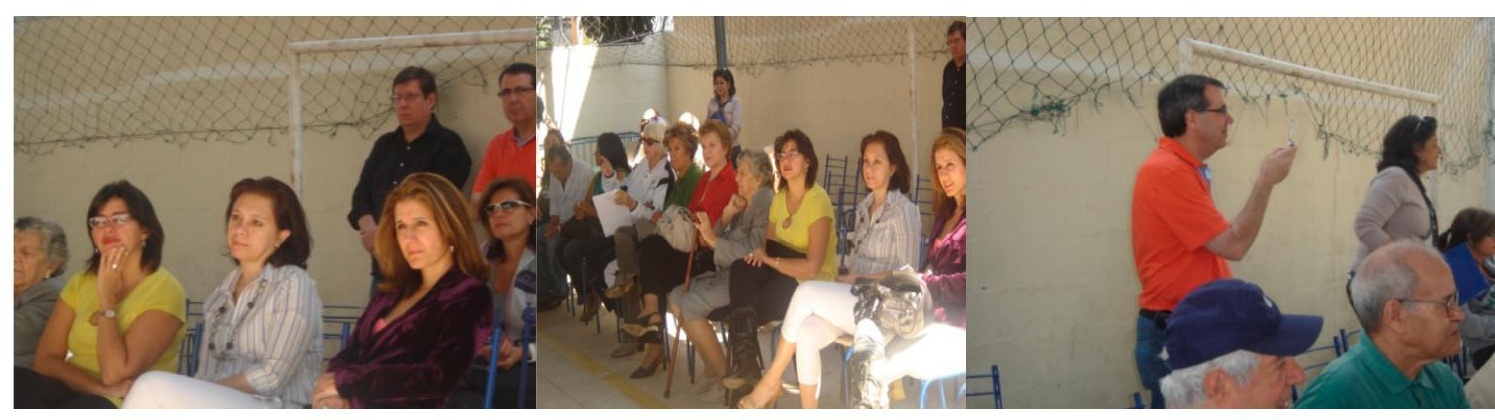

E, nas arquibancadas ficaram os indígenas:

Figura 6 Indígenas convidados. 20/07/2008. São Paulo (SP) Autora: Dora Pankararu.

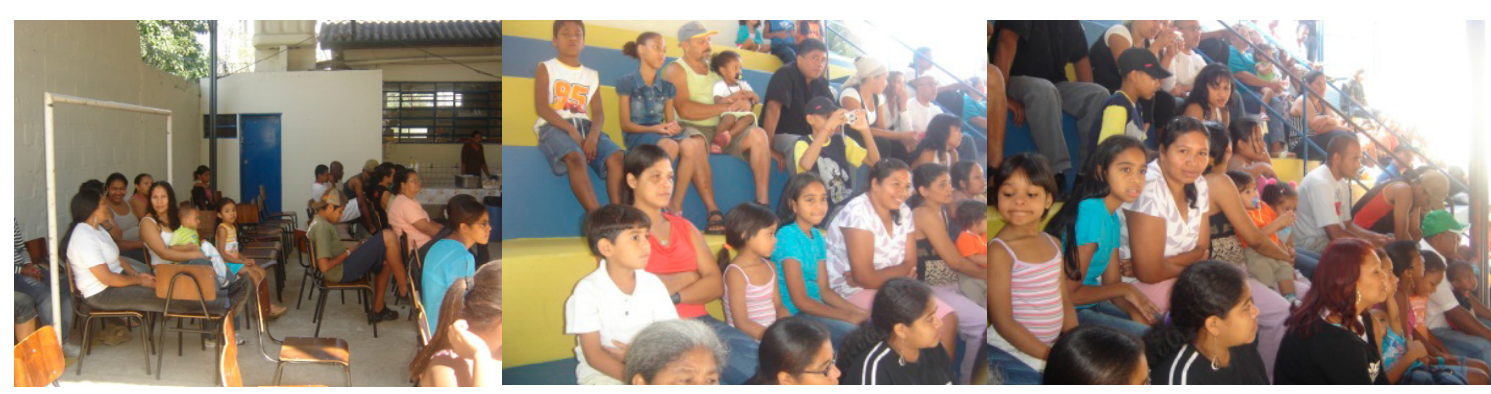

Nessa ocasião o tom "político" foi acentuado no discurso de apresentação da comunidade Pankararu feito por Dora e no discurso feito por Bino em um pequeno intervalo da dança dos praiás. Já a apresentação do evento feita pelo Dr. Sodré acentuou o aspecto "cultural" do evento, disse ele: "a razão principal de nós estarmos hoje aqui é de mostrar a dança da tribo Pankararu. Os Pankararu são maioria na favela do Real Parque". Afirmou ainda que o projeto social da SARP era o de conseguir um espaço para os Pankararu poderem "vivenciar a sua cultura". Em seguida, ele passou a palavra a Dora para que ela explicasse como seria a dança.

Após a "apresentação", conforme o protocolo, "Rosalie convida as autoridades e convidados da SARP e o representante dos Pankararu, Sr. Bino, a 
se dirigirem para o refeitório e os índios Pankararu tomarão o lanche que será oferecido na própria quadra próxima as pias e bebedouros.". O lanche foi servido para os Pankararu na quadra e as "autoridades" e "convidados" subiram para o refeitório.

Eu estava no meio da quadra e a diretora Rosalie passou por mim e meio desconfiada falou: "você quer ficar aqui ou quer subir, você que sabe, se quiser ficar aqui embaixo também...". Eu estava em uma posição ambígua, aparentemente "lá e cá", não tinha um lugar exato nesse evento, o antropólogo que filma, eu era então um dos "convidados e autoridades" ou um dos "indígenas", outro e outro eu era naquele momento, e podia escolher me servir de um deles, mas o fato de que eu fui convidado a subir me deixava menos do que a escolha a certeza de que eu fora alocado em uma posição definida como "superior". Dora então perguntou "vai subir ou ficar ai?", respondi "posso?", "vamos", ela falou.

Subi com Dora e Bino, os únicos indígenas que se juntaram as "autoridades" e "convidados" da SARP. O lanche servido no refeitório era o mesmo da quadra, cachorro-quente. Conheci melhor o Sr. Sodré e alguns dos moradores dos prédios e casas do Real Parque, membros do grupo que popularmente são chamados de "a elite do bairro", os tais "convidados". O assunto discutido foi bem trivial e sobre amenidades, sendo o mais significativo o discurso dessas pessoas sobre a história do bairro e como aquilo era diferente, como antigamente o bairro era muito diferente. Além desses "convidados", chamados de "os antigos moradores do bairro", pude conhecer também algumas das "autoridades presentes", a Supervisora de Esportes da Subprefeitura de Pirituba/Jaraguá da cidade de São Paulo, Adriana Jacqueline Cunha Cortez, e também Supervisora de Assistência Social da Subprefeitura de Pirituba/Jaraguá da cidade de São Paulo, Ana Rosa Costa Ribeiro Maia. Ambas conheciam muito bem a questão indígena em São Paulo já que trabalhavam na subprefeitura que é responsável pela região da cidade onde estão duas aldeias Guarani, no Pico do Jaraguá. Elas estavam particularmente interessadas em combinar com a SOS-CIP a presença deles nos jogos indígenas na cidade.

Essa "apresentação" foi realizada em um contexto muito específico, o da reurbanização do bairro do Real Parque. Esse contexto é paradigmático do "lugar" que assume por vezes a performance da dança dos praiás em São Paulo. A questão era: por que, em um evento cujo tema implícito era o da reurbanização do bairro do Real Parque, o tema explícito foi o da "cultura" Pankararu com a "apresentação" de sua dança típica? Por que uma reunião com os Pankararu e a SOS-CIP foi preterida e no lugar aconteceu apenas 
a "apresentação" da dança dos praiás? O que essa "apresentação" fez funcionar nesse contexto?

A escolha da SARP pela "apresentação" da dança dos praiás ao invés de uma reunião com os Pankararu pretendia servir naquele momento de um espaço de consenso e de aliança entre os "antigos moradores", ou seja, os moradores dos prédios de luxo do Real Parque e a comunidade da favela do Real Parque. E isso porque os Pankararu, por conta de seu associativismo, assumiram um importante papel de protagonismo social na favela onde, pretensamente, "dividem forças" com diversas outras entidades mantidas na comunidade, dentre elas um grupo organizado que monopoliza o comercio de drogas ilegais em São Paulo, o PCC (Primeiro Comando da Capital).

Os Pankararu, através da SOS-CIP, assumiram uma liderança política na favela, devido tanto a sua condição de indígenas como também ao grande número de membros da etnia na favela, um sexto dos moradores. Essa liderança política é dividida com várias outras entidades como ONGs que atuam no local e associações de ofício e de moradores. Mas além desse vasto grupo existia também uma importante força política no local, o PCC, grupo que monopolizava, há pouco mais de dez anos, o comércio de drogas ilegais na favela do Real Parque e região (Jardim Panorama e outras). Dessa forma os Pankararu eram uma das principais entidades associativas, dentre inúmeras existentes na favela, escolhidas pelas instituições mantidas por moradores "ricos" do Morumbi (por exemplo, associação de amigos do bairro, entidades beneficentes, órgão da igreja e outros), como o interlocutor privilegiado entre os moradores dos prédios e mansões e a comunidade da favela em seu entorno.

Um exemplo muito interessante de como a SOS-CIP e os Pankararu se constituem em um diferencial étnico pode ser tomado no seguinte caso, contado por seu Bino. Em uma ocasião um rapaz indígena embriagado estava numa noite em cima de uma laje e se "mostrava" (exibia o pênis) e "mexia" com as mulheres que passavam, se exibindo e falando palavrões. Membros do PCC o retiraram da laje e começaram a "Ihe dar uma lição", com tapas e chutes, e ao mesmo tempo o molhavam com água gelada. No meio dessa tortura o rapaz disse que era indígena. Ao dizer isso, aqueles que estavam batendo nele pararam e questionaram se ele era indígena mesmo. Ele disse que sim, dessa forma uma dupla foi até a casa de seu Bino e relatou o que estava acontecendo. Ele, então, os acompanhou até o rapaz e confirmou que ele era indígena. Os membros do PCC disseram, então, que o caso não era da responsabilidade deles e sim de Bino que era 
"o cacique dos índios". Disseram que a sorte do rapaz era que ele era índio, senão a coisa "ia ficar muito feia pra ele". Além disso, disseram que Bino tinha responsabilidade sobre os indígenas e que ele tinha de "tomar conta do povo dele". Bino então levou o rapaz para a sua casa e no dia seguinte o acompanhou até os líderes do PCC para que ele se desculpasse com eles. Novamente, os membros do PCC afirmaram que o rapaz teve sorte "por ser índio".

Portanto, a SOS-CIP transformou-se num interlocutor privilegiado tanto entre parte dos moradores do bairro do Morumbi que não frequentavam os espaços da favela quanto entre aqueles que representavam um poder ilegal de coerção política, financeira e física dentro da comunidade. A opção da SOS-CIP não era a de ser "surda" para nenhum dos lados, pois tal procedimento apenas tornaria inviável a convivência com a multiplicidade das questões sociais ali envolvidas. Ao optar por estar "aberta" ao diálogo e promover processos transitórios e temporários de conciliação, a SOS-CIP promovia tanto a "paz" quanto servia de ponto de consenso das diversas demandas.

O PCC havia procurado a SOS-CIP para argumentar em favor da permanência da comunidade indígena naquele local, mesmo com a reurbanização da favela. Esse pedido se baseava no fato de que muitos moradores da comunidade, após a reurbanização, vendiam seus apartamentos tendo em vista o rápido processo de gentrificação (especulação imobiliária) que o projeto de reurbanização promovia. Um barraco que custava, em 2008, no máximo, $R \$ 5.000,00$ podia virar um apartamento de até $R \$ 50.000,00$. A possibilidade de alternância constante dos moradores que compunham a comunidade da favela, podia se configurar na perda do controle que o PCC exercia sobre aquele "território" e, com isso, afetar sua segurança e, consequentemente, suas atividades.

A opção da SOS-CIP foi, pelo menos no início do debate, deixar que cada morador decidisse por si mesmo, já que o projeto de reurbanização se constituía em um projeto de longo prazo com debates que vinham sendo mantidos como várias instituições públicas, instituições e associações comunitárias no Real Parque e que veem se estendendo até hoje sem um projeto definitivo. A posição da SARP ao procurar criar vínculo com os Pankararu através do convite da SOS-CIP, era a de promover o processo de reurbanização da região sem a criação de conflitos entre os grupos interessados na manutenção de certo padrão organizacional e "territorial" e na promoção de um novo padrão urbanístico. O modelo de reurbanização, tal como aparentemente defendia a SARP naquele momento, aproveita- 
ria a especulação imobiliária que o projeto possivelmente promoveria para agregar valor econômico ao já muito valorizado bairro do Morumbi e Real Parque. O modelo defendido pela SARP era o da "pacificação" através do incremento do poder público e da melhoria na condição de moradia da favela. Essa reurbanização poderia significar a mudança de parte da comunidade e uma relativa mudança da condição social dos moradores dos prédios que substituiriam a favela.

\section{Conclusão: encanto e fetiche da performance}

Após o evento citado acima, eu comentei com Dora que seria interessante se ela, na apresentação do grupo que realizaria a performance da dança dos praiás, falasse sobre os aspectos simbólicos e cosmológicos da dança dos praiás de forma a intensificar a curiosidade da audiência. Ela respondeu, praticamente sem pensar: "Marcos, esse povo não tá interessado nisso. Eles não querem saber desses detalhes, dessas coisas, eles querem mesmo é só ver a dança". Naquele momento eu não concordei com essa afirmação, mas o tempo e o trabalho de campo me mostraram que a experiência dela estava correta, esse nosso diálogo foi fundamental para a construção de minha pesquisa.

A partir daquele momento passei a procurar na história imagética da SOS-CIP a forma como essa entidade era mostrada e tematizada nas ocasiões em que ela tinha visibilidade, e passei a concordar com Dora que, por mais detalhes etnográficos que os Pankararu dessem e mostrassem, esses detaIhes muito raramente eram valorizados pela audiência paulista das arenas onde a SOS-CIP tinha acesso. De fato, o que tais arenas queriam era apenas um "conteúdo" que preenchesse uma demanda prévia, evitando assim a novidade e, portanto, o diálogo que promove mudanças de comportamento de tais audiências.

Embora essa constatação tivesse aparecido de maneira negativa para mim, ao longo do trabalho de campo passei a perceber que essa alienação da audiência paulista não era somente fomentada por sua idiossincrasia, mas era também bastante valorizada pela própria SOS-CIP. Do ponto de vista da SOS-CIP, o apelo ao exótico das arenas paulistas servia como proteção para os "segredos" dos Pankararu. "Segredos" rituais e cosmológicos, pois Dora sempre dizia que eles estavam "abertos" por conta dessas demandas, mas não "mostravam tudo", ou seja, embora os praiás ali estivessem numa "abertura" contextual, essa "abertura" não mostrava tudo. 
Assim, por mais críticas que se possa fazer a essas arenas em São Paulo, é preciso reconhecer que elas possibilitavam aos Pankararu e a SOS-CIP uma presença política mais forte e ao mesmo tempo a atualização de parte de seu sistema cosmológico e ritual. Essas arenas possibilitam uma reflexibilidade sobre sua etnicidade e sobre a identidade de indígenas Pankararu.

O ingresso nessas arenas não era franqueado sem que existisse uma série de negociações bastante complexas e que raramente chegavam a ser propriamente verbalizadas. Ao longo desse texto procurei mostrar como essa negociação não verbal pode ser percebida e discriminada pela análise antropológica (e outras ciências correlatas). A imagem da dança dos praiás, como signo de alteridade positivo era, concluí afinal, produto de uma cultura política e de uma política cultural da SOS-CIP, cuja atividade acabara por atualizar, em um modelo inédito, o complexo ritual Pankararu.

\section{Referências}

ALBUQUERQUE, Marcos. A. S.. O regime imagético Pankararu: Performance e arte indígena na cidade de São Paulo. 01. ed. Florianópolis: EDUFSC, 2017.

BAUMAN, Richard. Verbal Art as Performance. Rowley, Mass: Newbury House Publishers, 1977.

BOURDIEU, Pierre. O Poder Simbólico. Lisboa, Difel, 1989.

CANCLINI, Néstor García. Consumidores e cidadãos. 6. ed. Rio de Janeiro: Editora UFRJ, 2006.

DEBORD, Guy. A sociedade do espetáculo: comentários sobre a sociedade do espetáculo. Rio de Janeiro: Contraponto, 1997.

FOUCAULT, Michel. História da Sexualidade I: A Vontade de Saber. Tradução de Maria Thereza da Costa Albuquerque e J. A. Guilhon Albuquerque. Rio de Janeiro, Edições Graal, 2009.

HALL, Stuart. Identidade cultural na pós-modernidade. Rio de Janeiro: DP\&A, 2006.

LANGDON, Esther Jean. Performance e sua Diversidade como Paradigma Analítico: A Contribuição da Abordagem de Bauman e Briggs. In: Anais do Colóquio Antropologias em Performance. Org. Vânia Cardoso. PPGAS/ UFSC, 2009.

NOVAIS, Sylvia Caiuby. Apresentação: Imagens de índios - signos da alteri- 
dade. In: Cadernos de Antropologia e Imagem: a imagem do índio no Brasil, vol. 12, $n^{\circ} 1,2001$.

OLIVEIRA, João Pacheco de. O Nosso Governo: Os Ticuna e o Regime Tutelar. São Paulo: Marco Zero, 1988.

VALLE, Carlos Guilherme Otaviano do. Experiência e semântica entre os Tremembé do Ceará. In: OLIVEIRA FILHO, João Pacheco de (org.): A viagem da volta: etnicidade, política e reelaboração cultural no Nordeste indígena, pp. 279-337. Rio de Janeiro: Contra Capa/ LACED, 1999.

- Identidade em Caucaia: etnografia e vicissitudes de uma perícia antropológica. In: Revista ANTHROPOLÓGICAS, 14(1-2):235-262, 2003.

Torém/Toré: Tradições e Invenção do Quadro de Multiplicidade Étnica no Ceará Contemporâneo. In: Toré: Regime Encantado dos Índios do Nordeste. Org. Rodrigo de Azeredo Grünewald, Ed. Massangana (FUNDAJ). Recife, 2005. 